\title{
The Effect of Real Estate Finance on the Financial Performance of Listed Commercial Banks in Kenya: A Panel Evidence
}

\author{
Fredrick Onyango Odhiambo \\ Department of Research, Research Pro Solutions, Nairobi, Kenya
}

\section{Email address:}

ombako82@gmail.com

\section{To cite this article:}

Fredrick Onyango Odhiambo. The Effect of Real Estate Finance on the Financial Performance of Listed Commercial Banks in Kenya: A Panel Evidence. Journal of Finance and Accounting. Vol. 3, No. 4, 2015, pp. 61-68. doi: 10.11648/j.jfa.20150304.11

\begin{abstract}
Over the years, real estate financing has been a preserve for mortgage financing companies. With time, commercial banks have started engaging in mortgage financing. With the rising non-performing loans among Kenyan banks, mortgages have seen as a safer bet to improve the loan portfolio performance. The study sought to investigate the effect of real estate finance on the financial performance of listed commercial banks in Kenya. Data for nine listed commercial banks was collected for the period 2009 - 2013 from the annual reports of the respective banks. Panel regression analysis was employed on the collected data. The results showed that real estate finance did not have a significant effect on the financial performance of listed commercial banks. Foreign ownership, market structure, cost of bank operations, and the size of the bank significantly influenced bank performance. The study concludes that real estate finance does not influence the financial performance of listed commercial banks. It is recommended that the Central Bank of Kenya (CBK) and stakeholders in the housing sector strategize to improve uptake of affordable mortgage loans in order to improve the overall performance of banks. This study contributes to literature by providing the link between real estate financing and the financial performance of banks from a developing country's perspective in Sub-Saharan Africa where housing demand is on the rise and therefore offers enormous opportunity for rapid growth for banks. Further areas for research are recommended.
\end{abstract}

Keywords: Real Estate, Mortgage, Central Bank of Kenya, Nairobi Securities Exchange, Kenya

\section{Introduction}

\subsection{Background}

Real estate financing has over the years been a preserve of mortgage financing companies but with time, commercial banks have started engaging in mortgage financing. An efficient housing finance system has significant importance both in meeting the housing needs of individuals and in reinforcing the development of the construction, finance and other related sectors of an economy. International experience suggests that, the widespread availability of residential mortgages has favourable impact on poverty alleviation, quality of housing, infrastructure, and urbanization (Erbas, 2005). Developed countries currently have very advanced housing finance systems in which funds flow from people with fund surpluses to the ones that have deficits and need the funds through the various channels provided by the mortgage markets. The situation in the developing countries is however very different in that real estate has remained largely under-developed despite the fact that sector players recognise the economic and social importance of the sector. This has been attributed to the unstable inflation rates experienced and the high level of unemployment (Dolde, 2006).

Real estate financing is the provision of finance or capital for purchase of housing or for own construction. Dymski (2007) defines real estate finance as the capital required for construction of housing or the resources required to acquire or access housing project by household or the credit supplied by housing finance institutions against some collateral. Internationally, there are various institutions that are involved in the lending of money for real estate projects and these include: commercial banks, mortgage finance firms, saving and loans co-operatives, insurance companies, government parastatals, pension funds, trusts and other real investment institutions (Lwali, 2008). Unlike unsecured loans, real estate financing is a form of a secured loan whereby the mortgaged property acts as the security for the loan extended by the 
lending institution (Macharia, 2013).

Real estate finance loans are generally structured as long-term loans, the periodic payments for which are similar to an annuity and calculated according to the time value of money formula. The most basic arrangement would require a fixed monthly payment over a period of ten to thirty years depending on the conditions of the agreement. Over this period, the principal component of the loan would be slowly paid down through amortization. In practice, many variants are possible and common worldwide and within each country (Tse, 2002).

The banking sector in Kenya was liberalised in 1995 and exchange controls lifted. The Central Bank of Kenya (CBK), which falls under The Treasury's docket, is responsible for formulating and implementing monetary policy and fostering the liquidity, solvency and proper functioning of the financial system. There are currently 43 commercial banks in Kenya with 11 of them listed in the Nairobi Securities Exchange (NSE). In order to improve their revenues, commercial banks in Kenya have moved into housing and consumer lending (Ng'ang'a, 2012). This trend has been going on among most of the commercial banks as they seek to diversify their loan portfolios and minimise the risks that come about as a result of the unsecured loans that are more popular in the country. For example, only about 5 percent of the banking system's credit went to real estate (RE) over 1997-2008 with a declining trend, about 6 percent to private households $(\mathrm{PH})$ with an increasing trend and 2 percent to consumer durables (CD) with an increasing trend. Building and construction (B\&C) took an average 5 percent (Kilonzo, 2008).

This study contributes to literature by providing the link between real estate financing and the financial performance of banks in Kenya, which is a developing country in the Sub-Saharan Africa. This perspective is important as there is a growing housing demand in Kenya hence offering enormous opportunity for rapid growth for commercial banks that choose to offer mortgage loans. The paper is structured as follows. The next section discusses the research problem. This is followed by a literature review on the effect of real estate financing on bank performance as well as other determinants of bank performance which are used in the study as control variables. The next section discusses the research methodology followed by the findings. Finally, a discussion of results and conclusions are made.

\subsection{Research Problem}

Kenya has a large housing gap which is growing every year and is increasingly prevalent in urban areas due to differences in income levels in the economy. The annual increase in demand for housing in Kenya is 206,000 units annually with 82,000 units required in urban areas. In 2011, the Ministry of Housing estimated that the formal supply of houses to the market reached 50,000 creating a 156,000 shortfall which added up to the 2 million units existing deficit. In 2012, it is estimated that further 85,000 units were also added to the backlog (CAHF 2012). While Kenya's mortgage market is growing, the industry is dominated by the large commercial banks indicating barriers to entry or high risk for medium and smaller banks. However, the growth rates indicate that the small sized banks have the fastest growth rate of 38 percent on average, followed by medium banks which are growing at 25 percent on average with large banks closely following at 24 percent on average (Ndungu, 2010).

The effects of real estate financing on the economy as well as on the performance of the financial sector in general has not been given a lot of focus by researchers in Kenya. A search for empirical literature on the determinants of performance of banks in general and the effect of real estate financing on the performance of banks in Kenya revealed the existence of only two studies. Macharia (2013) evaluated the effects of global financial crisis on the financial performance of banks offering mortgage finance and Ndururi (2012) evaluated the effects of mortgage on the financial performance of all commercial banks in Kenya. There is therefore a gap in literature as far as the study on the effects of real estate financing on the financial performance of listed commercial banks in Kenya is concerned, a gap which this study addresses. The following research question was therefore explored: does real estate financing influence the performance of listed banks in Kenya?

\section{Literature Review and Hypotheses Development}

A few studies have empirically examined how bank performance is influenced by mortgage or real estate finance. Mostly, scholars have devoted their time to examine the determinants of mortgage financing or bank performance. This section reviews empirical studies that have examined how mortgage loans or real estate finance in general influence financial performance of banks as well as other factors that influence bank performance.

\subsection{Mortgage Loans and Bank Performance}

According to Lipunga (2014), real estate financing for banks is seen as a diversification strategy which is usually expected to lower the risks associated with loss through unsecured non-performing loans (NPLs). Since mortgage financing requires borrowers to put in some savings as down payment for the property, it lowers the ratio of NPLs (Kimeu, 2008).

The empirical studies on the relationship between mortgage loans and bank performance have produced conflicting results. For instance, Kuo et al. (2010) found that loan policies have a significant negative effect on the performance of commercial banks. The study had examined the impact of IT loans on the performance of banks in Taiwan using a panel data covering the period from 1998 to 2002. While the study did not specifically address how mortgage loans influence bank performance, it offers an insight into how a loan policy may influence the financial performance of banks.

Further, Dirnhofer (2012) also found that mortgage loans significantly influence the performance of banks. The author had examined whether mortgage backed securities influenced 
the performance of top 375 banks in USA during the 2007 financial crisis. This study was important as it contributed to research by examining how the performance of banks that were engaged in mortgage financing were impacted by the financial crisis. Its major limitation was the focus on the US market alone. Therefore, its results cannot be generalised to developing countries like Kenya.

In Kenya, Ndururi (2013) using primary data found that banks use mortgage financing to improve their overall performance. The study had assessed the effect of mortgage income on the financial performance of banks. The authors collected primary data by interviewing respondents from 44 banks in Kenya. While the author attempted to show how mortgage finance influences bank performance, the use of interviews is not reliable enough to conclude on whether bank performance is influenced by mortgage finance. This was the major limitation of the study hence the need to further test this relationship using panel data.

The study by Krainer \& Laderman (2011) did not find evidence of a significant effect of mortgage loans on the performance of commercial banks. The authors had sought to investigate how mortgage loan securitization influences relative loan performance in California. The study covered the period between January 1, 2000 and December 31, 2007. The major limitation of this study was its focus on California, which makes the results of the study difficult to generalise for other banks outside USA and especially in Sub-Saharan Africa.

These conflicting results suggest that more studies need to examine this issue in order to ascertain the effect of mortgage finance on the performance of banks. Given the dearth of literature on the same in Kenya, the first hypothesis tested is as follows:

Hypothesis 1: The size of mortgage loans relative to the total loans affect the financial performance of commercial banks.

\subsection{Other Determinants of Bank Performance}

The study by Demirguc-Kunt \& Huizinga (1999) noted that financial development and structure variables are important in determining the financial performance of commercial banks. According to Wood (2003), industry concentration has a positive impact on the financial performance of commercial banks. In Kenya, Kamau \& Were (2013) showed that market structure was a major source of superior performance for banks. However, some studies have found conflicting results. For instance, Naceur (2003) reported a negative relationship between industry concentration and the financial performance of commercial banks in Tunisia. Karasulu (2001) also noted that the increasing industry concentration in Korea was not a guarantee that there would be improved financial performance of commercial banks. Further, Amare (2012) found no evidence of the presence of market concentration of banks in Ethiopia and therefore failed to test its effect on bank performance. Thus, there is conflicting results on whether and how market structure affects bank performance. This leads to the second hypothesis:
Hypothesis 2: Market structure affects the financial performance of commercial banks in Kenya.

The cost of operations, normally expressed as a percentage of profits, is usually expected to negatively affect bank performance. Operating expenses is usually used as a measure of cost of operations and are supposed to proxy efficiency of management. Thus, majority of studies have found a negative effect of costs of operations on bank performance. For instance, Ayele (2012) found that managerial efficiency had a strong influence on profitability of banks in Ethiopia. Amare (2012) also showed that expense management negatively influenced profitability of commercial banks in Ethiopia. Further, Swarnapalia (2014) noted that operating expenses had a strong effect on bank performance. However, a few studies have found different results. For instance, Kamau \& Were (2013) found no evidence that efficiency significantly influenced the performance of commercial banks in Kenya. Gyamerah \& Amoah (2015) found no evidence that expenses affected the financial performance of banks in Ghana. Ongore \& Kusa (2013) found that management efficiency had a positive effect on all performance measures used in the study. The conflicting results lead to the following hypothesis:

Hypothesis 3: The cost of operations affect the financial performance of commercial banks in Kenya.

Ownership status of the bank is another firm specific factor that has in the recent past drawn a lot of attention from researchers in financial management who are interested in evaluating the determinants of the financial performance of commercial banks. The literature on this has mainly focused on the influence of foreign ownership on financial performance as compared to the influence of domestic ownership on the financial performance of commercial banks. According to Athanasoglou, Brissimis \& Delis (2008), foreign ownership leads to better financial performance of commercial banks in developing countries. Kiruri (2013) also found that foreign ownership had a positive effect on bank performance in Kenya. However, some studies have also given conflicting results. For instance, Abdul-Rahman \& Reja (2015) found that foreign ownership had a negative and significant effect on bank performance (measured as ROE) in Malaysia. Gyamerah \& Amoah (2015) also found that foreign ownership had a negative effect on bank performance. The study by Ongore \& Kusa (2013) found no evidence of the effect of foreign ownership on the financial performance of banks in Kenya. Given the conflicting results, it is worthy to examine how ownership status, and especially foreign ownership, influences the performance of banks in Kenya. Thus:

Hypothesis 4: Foreign ownership affects the financial performance of commercial banks in Kenya.

Size of the bank has been at the centre of many performance studies in the banking industry. A number of studies have found that size positively influences performance of banks. The study by Goddard et al. (2004) notes that an increase in the bank's size has a positive influence on the financial performance of that bank due to the fact that the cost of seeking capital for that bank is reduced significantly. In 
Ethiopia, Ayele (2012) found that bank size had a strong influence on bank performance. Further, Swarnapalia (2014) found that the size of the bank influences the financial performance of banks. In Ghana, Gyamerah \& Amoah (2015) found that size had a positive influence on bank profitability. Tariq et al., (2014) found that for Pakistani banks, size influenced their performance. In contrast, some studies have found negative effects of size on bank performance. For instance, Amare (2012) found that size had a negative influence on bank performance. This leads to the following hypothesis:

Hypothesis 5: The size of the bank affects the financial performance of banks in Kenya.

Capital is the amount of own fund available to support the bank's business and act as a buffer in case of adverse situation (Athanasoglou, Sophocles \& Matthaios, 2005). A number of studies have examined how bank performance is influenced by capital adequacy. Some of these studies include Ayele (2012) who found that capital adequacy had a strong influence on bank profitability. Staikouras and Wood (2003) found a positive link between a greater equity and financial performance among European Union (EU) commercial banks. According to Mathuva (2009), core capital ratio has a positive relationship with bank profitability in Kenya. Other studies have found conflicting results. For instance, Swarnapalia (2014) showed that capital strength ratio did not have a significant effect on bank performance. Further, Ongore \& Kusa (2013) found that capital ratio had a positive effect on Return on Assets (ROA) and Net Interest Margin (NIM) while it had a negative effect on Return on Equity (ROE) for commercial banks in Kenya. Gyamerah \& Amoah (2015) found a negative effect of capital adequacy on the performance of banks in Ghana. The study hypothesizes that:

Hypothesis 6: Capital adequacy affects the financial performance of commercial banks in Kenya.

Liquidity of the commercial bank is also considered to have an influence on the financial performance of the bank. Researchers note that insufficient liquidity of commercial banks is considered to be one of the major reasons why they fail. It is however important to note that when a commercial bank holds a lot of liquid assets, then it incurs an opportunity cost of getting higher returns from investing those assets. The study by Bordeleau \& Graham (2010) found that profitability is improved for banks that hold some liquid assets and that there is a point at which holding further liquid assets diminish bank profitability. Further, Alzorqan (2014) noted that liquidity has a significant effect on bank performance in Jordan. Some studies have found conflicting results. For instance, Swarnapalia (2012) revealed that liquidity risk did not influence bank performance. Gyamerah \& Amoah (2015) found that liquidity did not influence bank performance. Ongore \& Kusa (2013) found no influence of liquidity on performance of commercial banks in Kenya. Further, Tabari,
Ahmadi \& Emami (2013) found that liquidity risk weakens the performance of banks. This leads to the following hypothesis:

Hypothesis 7: Liquidity influences the financial performance of commercial banks in Kenya.

It is noted that generally, high inflation rates lead to high interest rates on loans and thus lead to higher income to commercial banks. A number of studies have empirically tested that effect of inflation (and other macroeconomic factors) on bank performance. For instance, Tabari et al. (2013) found that inflation and Gross Domestic Product (GDP) improved the performance of banks. Ayele (2012) found that macroeconomic factors (especially GDP) strongly influenced bank performance. Amare (2012) also revealed a positive contribution of GDP on bank performance in Ethiopia. The effect of inflation on the performance of commercial banks in Kenya was also investigated by Ongore \& Kusa (2013) and the results showed that inflation had a negative influence on bank performance. In the same study, GDP was found to have a negative effect on NIM. The study by Gyamerah \& Amoah (2015) found that inflation had no effect on the performance of banks in Ghana. Thus:

Hypothesis 8: Inflation rate influences the financial performance of commercial banks in Kenya.

\section{Methodology}

The population of this study was all the 11 listed commercial banks on the NSE as at December 2014. However, only data for ten banks was available and one of the banks only offered mortgage loans. The final sample was therefore nine banks. Secondary data was sourced from the annual reports that are available from their websites, the NSE and the Central bank of Kenya website. Panel data was collected for a period of 5 years from 2009-2013 as this period was considered long enough to take care of the cyclical nature of performance in banks. While this period includes the 2007-2008 financial crisis period which has been examined by various scholars, Kenya did not severely experience the effects of sub-prime mortgage crisis and therefore no effort was made to separate the financial crisis period. As Mwega (2010) explained, African banks are insulated from foreign finance as they rely on domestic deposits and lending and do not have derivatives or asset-based securities among their portfolios.

Panel regression was carried out to test the influence of the variables on the financial performance of the listed commercial banks using Stata. The model was tested for statistical significance at a level of significance of 0.05 . The study used the following model which is operationalised in Table 1. Financial performance is the dependent variable with mortgage size as the independent variable. The rest of the variables in the model are control variables.

$$
\mathrm{ROA}=\alpha+\beta_{1} \mathrm{MORT}+\beta_{2} \mathrm{MKT}+\beta_{3} \mathrm{COST}+\beta_{4} \mathrm{FOR}+\beta_{5} \mathrm{SIZE}+\beta_{6} \mathrm{CA}+\beta_{7} \mathrm{LIQ}+\beta_{8} \mathrm{INFL}
$$


Table 1. Operationalization of Variables.

\begin{tabular}{lll}
\hline Symbol & Definition & Measurement \\
\hline ROA & Financial performance & Ratio of net income to total assets \\
MORT & Mortgage size & Ratio of mortgage loans over total loan portfolio \\
MKT & Market Structure & Ratio of Bank asset to GDP \\
COST & Operational costs & Natural logarithm of costs of operations \\
FOR & Foreign ownership & An indicator equal to 1 if a firm is foreign owned \\
SIZE & Size of Bank & The natural logarithm of the book value of total assets \\
CA & Capital Adequacy & Ratio of bank's capital risk weighted credit exposures \\
LIQ & Liquidity & Ratio of banks liquid assets to short-term liabilities \\
INFL & Inflation & Inflation rate \\
\hline
\end{tabular}

\section{Research Findings}

\subsection{Descriptive Results}

A panel trend analysis in Fig. 1 shows the trend of mortgage loans for the period under study for each of the nine commercial banks. The results show a growth in the mortgage loans for Kenya Commercial Bank, Cooperative Bank of Kenya, Barclays Bank and Equity Bank. Some of the banks such as Standard Chartered Bank, National Bank of Kenya, and Diamond Trust have recorded a decline in mortgage loan as a ratio of total loans while CFC Stanbic's mortgage size has largely remained flat.

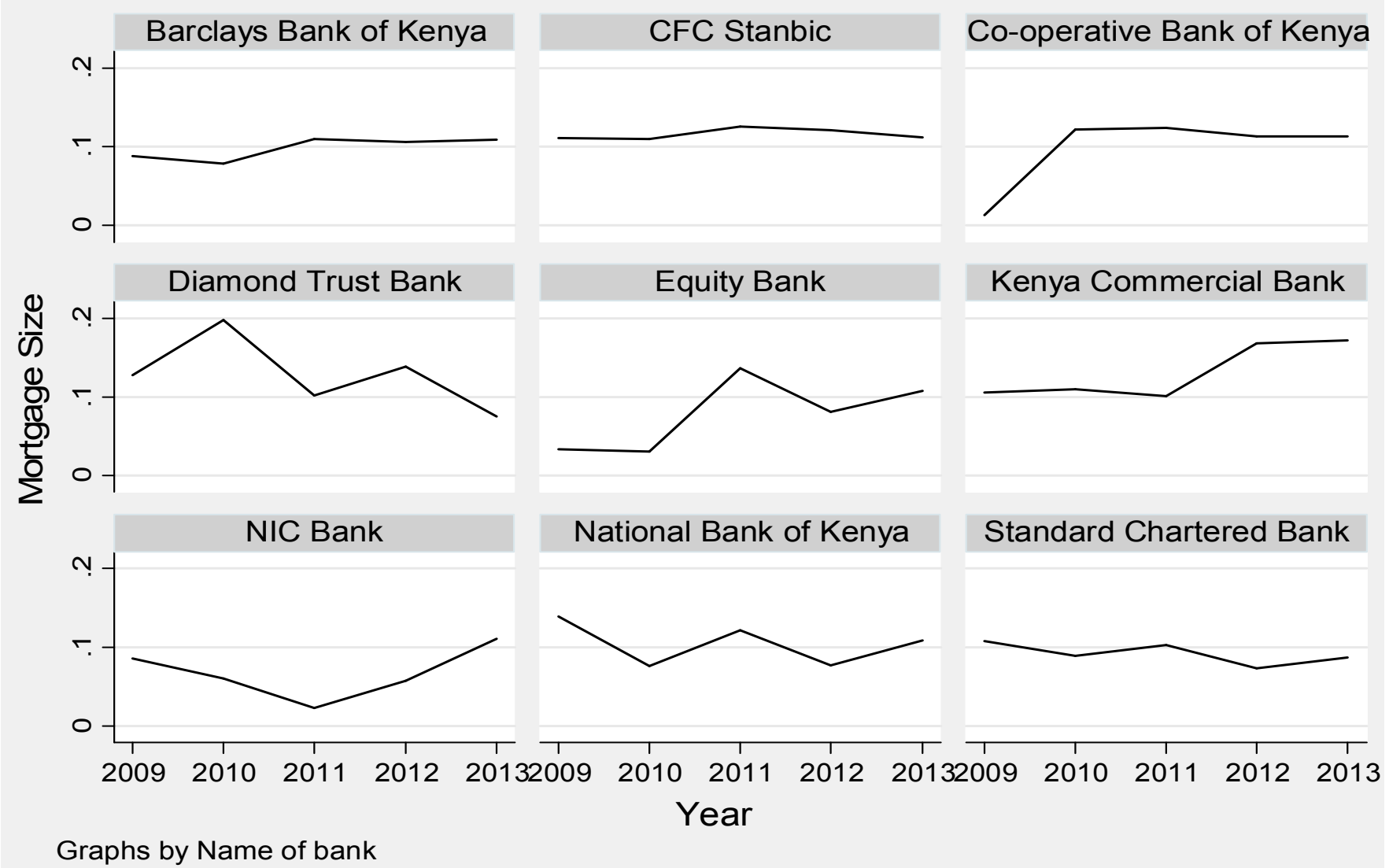

Figure 1. Individual bank trend of mortgage loans in Kenya 2009-2013.

Table 2 shows the summary of descriptive analysis results for all the variables in the study in terms of the mean scores, the median, and the standard deviation. As shown, a panel data was collected from 9 listed banks over a period of five years giving a total of 45 observations that were used in the study for analysis. The average performance as measured by ROA was 5.1 with a standard deviation of 1.9. The mean mortgage loan was 0.101 (or 10.1 percent) of the total loans with a standard deviation of 3.6 percent. 
Table 2. Summary Descriptive Results.

\begin{tabular}{|c|c|c|c|c|c|c|c|c|c|}
\hline & ROA & MORT & MKT & COST & FOR & SIZE & CA & LIQ & INFL \\
\hline Mean & 5.104 & 0.101 & $3.87 \mathrm{E}-06$ & 7.205 & 0.333 & 11.728 & 0.261648 & 0.843 & 8.460 \\
\hline Median & 5.077 & 0.108 & $3.91 \mathrm{E}-06$ & 7.280 & 0.000 & 11.865 & 0.251519 & 0.845 & 9.200 \\
\hline Max & 10.528 & 0.198 & $8.74 \mathrm{E}-06$ & 8.663 & 1.000 & 12.862 & 0.443930 & 0.925 & 14.000 \\
\hline Min & 1.593 & 0.013 & $1.54 \mathrm{E}-06$ & 6.103 & 0.000 & 10.766 & 0.124869 & 0.734 & 4.000 \\
\hline SD. & 1.897 & 0.036 & $1.86 \mathrm{E}-06$ & 0.741 & 0.477 & 0.529 & 0.066796 & 0.040 & 3.492 \\
\hline Obs & 45 & 45 & 45 & 45 & 45 & 45 & 45 & 45 & 45 \\
\hline
\end{tabular}

Key: ROA = Return on Assets; MORT = Mortgage loans; MKT = Market Structure; SIZE = Size of the bank; CA = Capital Adequacy; COST = Cost of Operations; FOR = Foreign Ownership; INFL = Inflation Rate; LIQ = Liquidity ratio.

\subsection{Panel Regression Results}

Table 3 shows the summary of regression analysis conducted on the data gathered. The table shows the correlation coefficients, the standard errors and the p-values for three models. The three models are presented alongside each other for purposes of comparison. First, a pooled OLS regression was run on the data (column 2). Then, a fixed effects model was run (column 3).

To decide on what model between pooled OLS and fixed effects was appropriate, an F-test analysis was carried out. The null hypothesis in an F-test assumes that pooled OLS is a better model than fixed effects model. The results led to the rejection of the null hypothesis as the F-test was significant $(\mathrm{F}$ $=45.08, \mathrm{p}<.05)$. Thus, fixed effects were present hence pooled OLS model was not sufficient to explain the relationship between real estate finance and bank performance.

The random effects model was then run (column 4). Breusch and Pagan LM test for random effects was carried out to test for the presence of random effects. The results were in favour the rejection of null hypothesis as the test was statistically significant $(\mathrm{F}=732.43, \mathrm{p}<.05)$. This suggested that random effects were also present. To determine which of these two models was a better model, a Hausman test was run. The test tests the hypothesis that random effects model is a better estimate.

The results of the hausman test, though in favour of the null hypothesis, were inconclusive. Attempts to conduct a random coefficients regression as suggested by scholars when no choice can be made between fixed effects and random effects model were futile as the panel was too small. Thus, random effects results are relied upon in this study.

Table 3. Regression Coefficients.

\begin{tabular}{llll}
\hline & Pooled OLS & Fixed Effects Model & Random Effects Model \\
\hline Mortgage size & $1.87(2.04)$ & $1.97(1.32)$ & $1.87(2.04)$ \\
Foreign ownership & $-0.38(0.15)$ & $0.00($ omitted $)$ & $-0.38(0.15)$ \\
Inflation rate & $0.00(0.02)$ & $0.00(0.01)$ & $0.00(0.02)$ \\
Market structure & $-325588(129571)$ & $-94656(145086)$ & $-325588(129571)$ \\
Cost of operation & $4.23(0.20)$ & $5.56(0.39)$ & $4.23(0.20)$ \\
Size of the bank & $-2.86(0.43)$ & $-5.13(0.59)$ & $-2.86(0.43)$ \\
Capital adequacy & $8.76(15.61)$ & $-0.51(9.63)$ & $8.76(15.61)$ \\
Liquidity & $10.26(25.93)$ & -3.16 & $10.26(25.93)$ \\
F-test (model) & 91.55 & 45.08 & 732.43 \\
DF & 36 & 29 & 29 \\
$\mathrm{R}^{2}$ & 0.9532 & 0.9158 & 0.9551 \\
Effect test & & 13.89 & 19.25 \\
$\mathrm{~N}$ & 45 & 45 & 45 \\
\hline
\end{tabular}

As shown in Table 3 from the random effects model, mortgage loan has a positive effect on the financial performance of listed commercial banks in Kenya although the effect is insignificant at 0.05 level, $\beta=1.87, p>.05$. This means that bank performance for listed banks in Kenya is not influenced by mortgage loans. Foreign ownership is found to negatively influence bank performance, $\beta=-0.38, p<.05$. As this effect is significant, this means that the performance of listed banks in Kenya is influenced by foreign ownership. In other words, foreign firms are more likely to record poor results than the domestic firms. The results also show that inflation rate has a positive but insignificant effect on bank performance, $\beta=0.00, p>.05$. This means that the performance of listed banks in Kenya is not influenced by the level of inflation rate. Further, market structure is significantly related with bank performance, $\beta=-325,558, \mathrm{p}<.05$. Thus, a one unit increase in market structure leads to a 325,558 units decline in bank performance. This shows that the structure of the market is a significant determinant of bank performance in Kenya. Surprisingly, the results show that the cost of operation significantly improves bank performance, $\beta=4.23, \mathrm{p}<.05$. Thus, a unit increase in the cost of funding leads to a 4.23 units increase in bank performance. The results also show that size of the bank has a significant effect on bank performance, $\beta=$ 
$-2.86, \mathrm{p}<.05$. In other words, an increase in bank size by one unit leads to a 2.86 unit decline in its profitability. The study also show that capital adequacy does not have a significant effect on bank performance, $\beta=8.76, p>.05$. Thus, performance of listed banks in Kenya is not influenced by the level of capital adequacy ratio. Finally, it is noted that liquidity has an insignificant effect on bank performance, $\beta=10.26$, $p>.05$. This shows that bank performance is unaffected by the level of liquidity.

\section{Discussion and Conclusions}

The purpose of this study was to examine the effect of real estate finance on the financial performance of listed commercial banks in Kenya in a bid to provide appropriate policy and practical recommendations to the industry regulators and players. The focus was on commercial banks listed on the Nairobi Securities Exchange. While there are currently eleven banks listed on the stock market in Kenya, one is not a commercial bank as it purely deals in mortgage finance, leaving the number of commercial banks listed to be ten. Of these, one did not have complete data for the period of analysis and was therefore left out of the sample. The analysis was therefore limited to nine listed banks. While this might be argued as small, it constitutes 21 percent of the total bank population in Kenya with asset values of 54 percent of total banking assets in Kenya. The sample was, therefore, considered adequate.

The descriptive results showed that mortgage loans averaged 10 percent of total loans. Bank specific mortgages showed positive growth in most of the banks while some showed negative growth. It may not be clear whether the falling growth in mortgage loan portfolios for some banks was as a result of the growth in overall loans which have affected the proportionate distribution of mortgage loans as compared to the overall total loans. Mortgage uptake has remained low in Kenya with mortgage loan accounts falling below 15 percent. I therefore expected that the mortgage loan accounts should be growing for all the banks surveyed. This is an area that requires further scrutiny to assess why the mortgage loans are not growing as they should.

The pooled OLS regression results as well as the random effects results were similar, though the random effects model was favoured. From the analysis, mortgage loans had positive but insignificant effect on the financial performance of listed commercial banks in Kenya. This shows that while mortgage loans may have led to an improvement in the net returns of commercial banks, their contribution to the overall performance was insignificant. Given that the median loan was 10 percent of the total loan portfolio for the listed banks, this may explain the insignificance of the loans to the overall bank profitability. These results are consistent with Krainer \& Laderman (2011) who found no evidence of privately securitized adjustable-rate mortgages performing worse than retained mortgages. The results are, however, in contrast with those of Kuo et al. (2010) in Taiwan, Dirnhofer (2012) in USA and Ndururi (2012) in Kenya. Given that Ndururi (2012) had used primary data, the reliability of the survey cannot be guaranteed. For Kuo et al. (2011) and Dirnhofer (2012), the studies were done in a completely different economic environment from Kenya and therefore may report varied effects as those of the current study.

The major limitation of this study is its focus on the listed banks in Kenya. A focus on all the commercial banks in Kenya would have provided a more definitive picture of the issue but given the data limitations for some of the banks, the choice was made to focus on the listed banks as they are required by law to publicly share their annual reports. The study recommends that since the current levels of mortgage finance have not improved the financial performance of banks, it is important to examine how mortgage finance can be used to improve the financial performance of banks in Kenya. The Central Bank of Kenya, together with stakeholders in the housing sector, should formulate policies that will spur uptake of mortgage loans. With a huge housing demand and a small mortgage loan size in the country, there is an enormous opportunity for stakeholders in banking and housing sectors to come together and recommend ways of meeting the housing needs through cheaper mortgage loan arrangements. Further studies can focus on affordable and sustainable financing methods in the real estate sector.

\section{References}

[1] Abdul-Rahman, A.N.A. \& Reja, A.F.M. (2015). Ownership Structure and Bank Performance. Journal of Economics, Business and Management, 3(5), 483-488.

[2] Alzorqan, S.T. (2014). Bank Liquidity Risk and Performance: An Empirical Study of the banking system in Jordan. Research Journal of Finance and Accounting, 5(12), 155-164.

[3] Amare, B.T. (2012). Determinants of Commercial Banks Profitability: An Empirical Evidence from the Commercial Banks of Ethiopia, MBA Thesis, Addis Ababa University.

[4] Athanasoglou, P.P., Brissimis, S.N. \& Delis, M.D. (2008). Bank-specific, industry-specific and macroeconomic determinants of bank profitability. Journal of International Financial Markets, Institutions and Money, 18(2), 121-136.

[5] Athanasoglou, P.P., Sophocles, N.B., Matthaios, D.D. (2005) Bank-specific, industry-specific and macroeconomic determinants of bank profitability. Working paper, Bank of Greece. 1(1), 3-4.

[6] Ayele, H.N (2012). Determinants of Bank Profitability: An Empirical Study on Ethiopian Private Commercial Banks, Unpublished MBA Project, Addis Ababa University.

[7] Bordeleau, E. \& Graham, C. (2010). The Impact of Liquidity on Bank Profitability. Bank of Canada Working Paper 2010-38.

[8] CAHF-Centre for Affordable Housing in Africa (2012). Year Book 2012: Housing Finance in Africa- a Review of some of African's Housing Finance Markets, Finmark Trust

[9] Demirguc-Kunt, A., \& Huizinga, H., (1998). Determinants of commercial bank interest margins and profitability: some international evidence. World Bank Economic Review, 13(1), $379-408$. 
[10] Dirnhofer, V. (2012). The Impact of Mortgage Backed Securities on Bank Performance during the Financial Crisis, Unpublished MSc Finance Project, Tilburg University.

[11] Dolde, M.J. (2006). Sources of Funds for Mortgage Finance. Journal of Housing Research, 1(1), 139-61.

[12] Dymski, G.A. (2007). From Financial Exploitation to Global Banking Instability- Two Overlooked Roots of the Subprime Crisis, University of California Center Sacramento Working Paper.

[13] Erbas, V.W. (2005). Information Finance Markets. Conclusions. New Agriculture is Transforming. Demand for Rural Financial Services.

[14] Goddard, J., Molyneux, P., \& Wilson, J.O.C. (2004). The profitability of European banks: a cross-sectional and dynamic panel analysis. The Manchester School, 72 (3), 363-381.

[15] Gyamerah, I.A. \& Amoah, B. (2015). Determinants of Bank Profitability in Ghana. International Journal of Accounting and Financial Reporting, 5(1), 173-187.

[16] Kamau, A., \& Were, M. (2013). What Drives Banking Sector Performance in Kenya? Global Business and Economics Research Journal, 2(4), 45-59.

[17] Karasulu, M. (2001). The Profitability of the Banking Sector in Korea. IMF Country Report, July.

[18] Kilonzo, S. (2008). Global Financial Crisis: Its Impact on Kenya and Possible Strategies to Mitigate the Effects. Capital Markets Authority Journal. 51(6), 145-168.

[19] Kimeu, T (2008). Credit risk management techniques on unsecured loans of commercial banks in Kenya, Unpublished MBA Project, UON.

[20] Kiruri, R.M. (2013). The effects of ownership structure on bank profitability in Kenya. European Journal of Management Sciences and Economics, 1(2), 116-127.

[21] Krainer, J. \& Laderman, E. (2011). Mortgage Loan Securitization and Relative Loan Performance. Federal Research Bank of San Francisco Working Paper 2009-22. Retrieved: http://www.frbsf.org/economic-research/files/wp09-22bk.pdf

[22] Kuo, H.C., Wang, L.H., Lai, Y.H., Yu, S., \& Wu, C. (2010). Loan Policy and Bank Performance: Evidence from Taiwan. Banks and Bank Systems, 5(2), 108-120.

[23] Lipunga, A.M. (2014). Determinants of Profitability of Listed Commercial Banks in Developing Countries: Evidence from Malawi, Malawi Polytechnic.

[24] Lwali, K. (2008). Challenges of International Housing Finance Institutions: a Case Study of Shelter Afrique. Unpublished MBA project, University of Nairobi.
[25] Macharia, E.W. (2013). The Effects of Global Financial Crisis on the Financial Performance of Commercial Banks Offering Mortgage Finance in Kenya. International Journal of Social Sciences and Entrepreneurship, 1(2), 688-701.

[26] Mathuva, D.M. (2009). Capital Adequacy, Cost Income Ratio and the Performance of Commercial Banks: The Kenyan Scenario. The International Journal of Applied Economics and Finance, 3(2), 35-47.

[27] Mwega, F.M. (2010). Global Financial Crisis Discussion Series Paper 17: Kenya Phase 2. Overseas Development Institute: London.

[28] Naceur, S.B. (2003). The Determinants of the Tunisian Banking Industry Profitability: Panel Evidence. Working Paper, Universite Libre de Tunis. Retrieved http://www.mafhoum.com/press6/174E11.pdf

[29] Ndungu, N. (2010). A Survey of Mortgage Financing by Commercial Banks in Kenya. Unpublished Research Project, University of Nairobi.

[30] Ndururi, L. (2013). Assessment of Effects of Mortgage on Financial Performance of Commercial Banks in Kenya. Unpublished MBA Project, Kenyatta University.

[31] Ng'ang'a T.W. (2012). Global Financial Crisis and Remittances. The Case of Kenya. Unpublished Research Project, University of Nairobi.

[32] Ongore, V.O. \& Kusa, G.B. (2013). Determinants of Financial Performance of Commercial Banks in Kenya. International Journal of Economics and Financial Issues, 3(1), 237-252.

[33] Staikouras, Ch., \& Wood, G. (2003). The determinants of bank profitability in Europe. Paper presented at the Proceedings of the European Applied Business Research Conference. Venice, Italy, June 9-13, 2003.

[34] Swarnapali, R.M.N.C. (2014). Firm Specific Determinants and Financial Performance of Licensed Commercial Banks in Sri Lanka, Proceedings of the 3rd International Conference on Management and Economics, 26-27 February 2014, Faculty of Management and Finance, University of Ruhuna, Sri Lanka.

[35] Tabari, N.A.Y, Ahmadi, M., \& Emami, M. (2014). The Effect of Liquidity Risk on the Performance of Commercial Banks. International Research Journal of Applied and Basic Sciences, $4(6), 1624-1631$.

[36] Tariq, W., Usman, M., Mir, H.Z., Aman, I., \& Ali, I. (2014). Determinants of Commercial Banks Profitability: Empirical Evidence from Pakistan. International Journal of Accounting and Financial Reporting, 4(2), 1-22.

[37] Tse, R.Y.C. (2002). Mortgage Default Risk and Lending Policy: A Study of the Mortgage Lending in Hong Kong. Australian Land Economics Review, 2 (1), 12-17. 